\section{A Case Study Documenting the Process by Which Biology Instructors Transition from Teacher-Centered to Learner- Centered Teaching}

Gili Marbach-Ad ${ }^{\text {t* }}$ and Carly Hunt Rietschel ${ }^{*}$

${ }^{\dagger}$ College of Computer, Mathematical and Natural Sciences and ${ }^{\ddagger}$ College of Education, University of Maryland, College Park, MD 20742

\begin{abstract}
In this study, we used a case study approach to obtain an in-depth understanding of the change process of two university instructors who were involved with redesigning a biology course. Given the hesitancy of many biology instructors to adopt evidence-based, learner-centered teaching methods, there is a critical need to understand how biology instructors transition from teacher-centered (i.e., lecture-based) instruction to teaching that focuses on the students. Using the innovation-decision model for change, we explored the motivation, decision-making, and reflective processes of the two instructors through two consecutive, large-enrollment biology course offerings. Our data reveal that the change process is somewhat unpredictable, requiring patience and persistence during inevitable challenges that arise for instructors and students. For example, the change process requires instructors to adopt a teacher-facilitator role as opposed to an expert role, to cover fewer course topics in greater depth, and to give students a degree of control over their own learning. Students must adjust to taking responsibility for their own learning, working collaboratively, and relinquishing the anonymity afforded by lecture-based teaching. We suggest implications for instructors wishing to change their teaching and administrators wishing to encourage adoption of learner-centered teaching at their institutions.
\end{abstract}

This is the analogy I thought of, the first semester was where you drop a ball on a hard floor, and at first it bounces really high, then the next bounce is a little lower, hopefully it's going to be a dampened thing, where we make fewer and fewer changes.

Alex

It seems to take a village to send a course in a new direction!!

Julie

\section{INTRODUCTION}

This study documents the process by which instructors transition from teacher-centered instruction to emphasizing learner-centered teaching in an introductory biology course. Weimer (2013) defines teacher-centered instruction as lecture-based teaching wherein students are "passive recipients of knowledge" (p. 64). She characterizes learner-centered teaching as "teaching focused on learning-what the students are doing is the central concern of the teacher" (p. 15). Weimer delineates five principles of learner-centered teaching, which are 1) to engage students in their learning, 2) to motivate and empower students by providing them some control over their own learning, 3) to encourage collaboration and foster a learning community, 4) to guide students to reflect on what and how they learn, and 5) to explicitly teach students skills
Nancy Pelaez, Monitoring Editor

Submitted June 20, 2016; Revised August 10, 2016; Accepted August 24, 2016

CBE Life Sci Educ December 1, 2016 15:ar62 DOI:10.1187/cbe.16-06-0196

*Address correspondence to: Gili Marbach-Ad (gilimaumd.edu).

(c) 2016 G. Marbach-Ad and C. H. Rietschel. CBE-Life Sciences Education (c) 2016 The American Society for Cell Biology. This article is distributed by The American Society for Cell Biology under license from the author(s). It is available to the public under an Attribution-Noncommercial-Share Alike 3.0 Unported Creative Commons License (http://creativecommons.org/ licenses/by-nc-sa/3.0).

"ASCB®" and "The American Society for Cell Biology®" are registered trademarks of The American Society for Cell Biology. 
on how to learn. Of note, various terms are used in the literature to refer to strategies that are related to learner-centered teaching (e.g., active learning, student-centered teaching).

The literature suggests that teacher-centered instruction as opposed to learner-centered teaching promotes memorization (Hammer, 1994) rather than desired competencies like knowledge application, conceptual understanding, and critical thinking emphasized in national reports (American Association for the Advancement of Science [AAAS], 2011). Further, lecturebased teaching fails to promote understanding of the collaborative, interdisciplinary nature of scientific inquiry (Handelsman et al., 2007). Notably, female and minority students have expressed feelings of alienation and disenfranchisement in classrooms using teacher-centered instruction (Okebukola, 1986; Seymour and Hewitt, 1997).

A recommended practice that can support implementation of learner-centered teaching is the use of the backward design (Wiggins and McTighe, 2005). The backward design model involves articulation of learning goals, designing an assessment that measures achievement of the learning goals, and developing activities that are aligned with the assessment and learning goals.

Despite robust evidence documenting the superiority of learner-centered teaching over teacher-centered instruction (as reviewed by Freeman et al., 2014), instructors continue to adhere to teacher-centered instruction. A recent study showed that the majority of faculty members participating in professional development programs designed to help them adopt learner-centered teaching practices continue to rely on lecture-based pedagogy as indicated by classroom observational data (Ebert-May et al., 2011). Possible reasons for such loyalty to lecturing include the following: 1) instructors' own personal experiences with lecture as undergraduates (Baldwin, 2009); 2) personal beliefs that transmission of knowledge to students through lecture is the best way to teach (Wieman et al., 2010); 3 ) the perception that lecture preparation is more time-effective than preparing learner-centered activities (Dancy and Henderson, 2010); 4) student resistance to active learning (Henderson and Dancy, 2007; Seidel and Tanner, 2013; Bourrie et al., 2014); 5) initial difficulties are often encountered when transitioning to learner-centered teaching, requiring several iterations to perfect a new teaching style; 6) learner-centered teaching encourages instructors to cover fewer topics in greater depth to promote meaningful learning (Weimer, 2013), and many instructors are uncomfortable with such loss of content coverage (Fink, 2013); and 7) the learner-centered instructor must change his/her role from an expert who delivers knowledge to a "teacher-facilitator," giving a degree of control over the learning process to students, and many instructors are uncomfortable with the unpredictability and vulnerability that comes with relinquishing control in the classroom (Weimer, 2013). Further, universities oftentimes fail to incentivize and encourage faculty members to prioritize teaching to a similar degree as research (Fairweather et al., 1996). It has been argued that the professional culture of science assigns higher status to research over teaching, encouraging scientists to adopt a professional identity based on research that typically ignores teaching (Brownell and Tanner, 2012).

Given that many instructors face challenges and intimidation while implementing learner-centered teaching in their classrooms, there is a need to explore their experiences and learn what support instructors need as they engage in the process of transforming their courses. Science education researchers have recently emphasized the critical need "to better understand the process by which undergraduate biology instructors decide to incorporate active learning teaching strategies, sustain use of these strategies, and implement them in a way that improves student outcomes" (Andrews and Lemons, 2015, p. 1).

Case studies have been shown as a useful tool to understand change processes (Yin, 2003). A case study approach represents a qualitative method of inquiry that allows for in-depth description and understanding of the experience of one or more individuals (Creswell, 2003; Merriam, 2009). Yin (2003, p. 42) provides a rationale for using single, longitudinal case studies that document participants' perspectives at two or more occasions to show how conditions and processes change over time. In this study, we used a case study approach to obtain an in-depth understanding of the change process of two university instructors (Julie and Alex) who were involved with redesigning a biology course. The instructors sought to transform the course from a teacher-centered, lecture-style class to one that incorporated learner-centered teaching. We interviewed the two instructors on multiple occasions; we also interviewed a graduate teaching assistant (GTA) and an undergraduate learning assistant (ULA) to gain their perspectives on teaching the course. We explored the motivation, challenges, and thought processes of the instructors during the interviews. We used several data sources in addition to the interviews to build the case study, including class observations by external observers and student feedback data.

Given that faculty members have difficulty changing their teaching, there are recommendations to use theoretical models of change to examine processes of change (Connolly and Seymour, 2015). We looked for theoretical models of change (Ellsworth, 2000; Rogers, 2003; Kezar et al., 2015) and found that the innovation-decision model (Rogers, 2003) has recently been used by science education researchers (Henderson, 2005; Bourrie et al., 2014; Andrews and Lemons, 2015). Therefore, we decided to use this model to theoretically approach our data. Specifically, we decided to use the adapted model developed by Andrews and Lemons (2015), which they modified to represent the change process that biology instructors experience when redesigning a course. This model includes the following stages: 1) knowledge, in which the instructor learns about the innovation and how it functions; 2) persuasion/decision, in which the instructor develops an attitude, positive or negative, toward the innovation and decides whether or not to adopt the innovation; 3) implementation, when the instructor behaviorally implements the innovation; and 4) reflection, in which instructor considers the benefits and challenges of using the innovation. On the basis of reflection, an instructor decides to stay with the present version of the implementation or to start the process once again in an iterative manner by seeking new knowledge (see Figure 1). According to Rogers (2003), a condition to begin the change process is that an instructor must be dissatisfied with his or her current teaching approach. Such dissatisfaction is one contributing factor leading an instructor to begin seeking new knowledge about new teaching strategies. Other external and internal factors usually influence an 


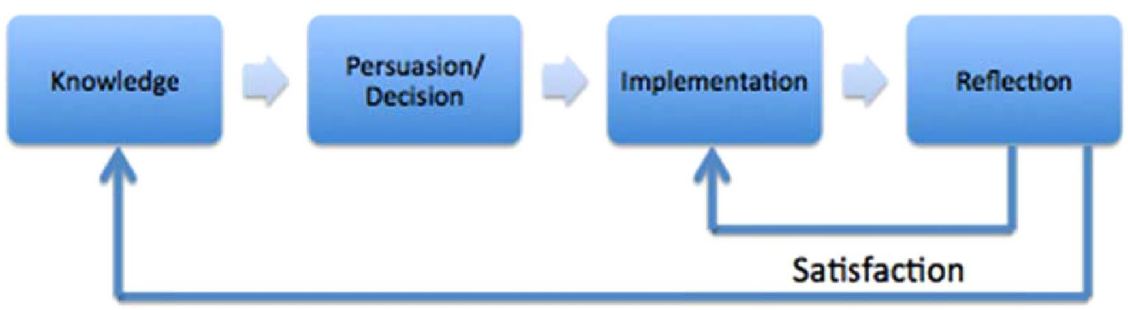

Dissatisfaction

FIGURE 1. Innovation-decision model adapted from Rogers (2003), Henderson (2005), and Andrews and Lemons (2015).

instructor's decision to change his or her teaching, including release time, institutional commitment, and instructor attitude (Andrews and Lemons, 2015).

\section{METHOD \\ Context of the Study}

This study was conducted at a research-intensive university on the East Coast of the United States. The instructors cotaught Principles of Biology III: Organismal Biology (BSCI207). BSCI207 follows two prerequisite courses, BSCI105 and BSCI106. BSCI105 covers molecular and cellular biology, while BSCI106 covers ecology, evolution, and diversity. BSCI207 requires students to synthesize concepts and principles taught in prerequisite courses, apply them across contexts in biology, and generally engage in higher-order learning (e.g., interdisciplinarity, conceptual understanding, quantitative reasoning). The course enrolls between 100 and 200 students per semester.

In Fall 2013, the provost's office distributed a call for grant proposals encouraging instructors to redesign their courses to incorporate evidence-based teaching approaches. The call specifically required applicants to design experimental studies to evaluate their course redesign approaches in comparison with their usual teaching approaches. Julie and Alex applied for the grant and were funded. Their proposed evidence-based teaching approach was to incorporate a series of small-group active-engagement (GAE) exercises throughout the semester. The traditional section would retain the usual three 50-minute lectures per week schedule. The experimental section would replace one 50-minute lecture with a shortened 20-minute lecture followed by a 30-minute GAE exercise with content matched to the traditional class occurring that day.

The instructors designed the GAEs to accomplish a series of learning goals that were consistent with Weimar's five principles of learner-centered teaching. For example, one of the GAE goals was to foster collaboration among students in order to mimic the scientific process of inquiry. This goal was in accord with Weimer's (2013) learner-centered teaching principle of collaboration, creating a learning community with a shared learning agenda, and modeling how experts learn. To accomplish this goal, the instructors implemented the GAEs in a smallgroup setting and required students to exchange ideas and achieve consensus on a single worksheet.

A second goal, which accords with Weimer's (2013) framework, was to engage students in their learning and

\section{Teaching Staff}

motivate them to take responsibility and control over their learning process. For example, one of the GAEs asked students to complete a humorous, fictional case study involving a spaceship captain and deadly neurotoxins. In this activity, students needed to use mathematical equations to calculate membrane potentials and to create simulations of conditions that impact membrane potential. Another activity was to collaboratively create a plot of ion transport rate versus concentration. Students were given a computer simulation that they used to generate data; they then entered the data into a Google documents Excel spreadsheet. This created a classroom database that was used to build the plot, which the instructor displayed using the lecture hall projector at the end of class. This activity involved multiple components of learner-centered teaching, including collaboration, student engagement, and student responsibility for learning. Detailed descriptions of a selection of GAEs are published elsewhere (Carleton et al., in press, 2017; Haag and Marbach-Ad, in press, 2017).

The provost grant offered funding that could be used for various purposes. The instructors decided to use the funding for summer salary to develop GAEs and to pay for support from a science education expert. Grant awardees were required to participate in Faculty Learning Communities (FLCs) and teaching workshops arranged by the campus teaching and learning center.

In Fall 2014, the instructors started to implement their experiment. Jeffrey, a third instructor, joined Alex and Julie to teach both sections; each of them was responsible for teaching several topics associated with their specific research expertise. In the GAE class, students were divided into small groups to complete a learning activity pertaining to the course topic. In total, 12 GAE sessions were held during the semester. Both GAE and traditional classes were taught in large auditoriums. For each GAE session, students self-selected into groups of three to five students. Four GTAs circulated among the groups to facilitate group work. Students were asked to leave empty rows around their respective groups to allow GTAs to move throughout the groups. This same topic was covered only by lecture format in the traditional class.

In Fall 2015, the instructors no longer conducted a comparative experiment while teaching. Julie and Alex continued to coteach the course with the GAE format with many modifications to the activities and other aspects of the course (see Results). Jeffrey continued to teach a different section of the course independently. Henceforth, we will describe the experience of Julie and Alex in their process of transforming the course.

Julie and Alex are associate professors. Lisa is a doctoral-level teaching assistant (TA) in the biology department. Lisa was a GTA in the Fall 2014 and Fall 2015 semesters. Jason was a freshman student in the GAE section of the Fall 2014 semester. In Fall 2015, Jason served as a guided study session (GSS) peer 
leader in BSCI207. GSS leaders are students who have taken a course on implementing evidence-based teaching approaches, and who have also completed the course they are tutoring with a high grade. GSS students are expected to facilitate smallgroup discussions outside class. Jason also volunteered to attend all GAE sessions to help facilitate.

\section{Data Collection Instruments}

Yin (2003) notes that multiple data sources are important in building case studies. As such, we use interview data, class observations, student feedback on the course, and information written in the grant proposal.

Interview Protocol. Julie and Alex were interviewed independently immediately following Fall 2014 for 20 minutes each. Julie was also interviewed independently in the beginning of Fall 2015 for 1 hour. Julie and Alex were interviewed together immediately following Fall 2015 for approximately 1 hour. Lisa and Jason were also interviewed following Fall 2015 for 20-30 minutes each. We used semistructured interview protocols (see the Supplemental Material) with additional questions to probe for clarification. The questions probed participants' motivation for change, attitudes toward change, barriers and challenges, administrative supports, details about the implementation, and teaching philosophies.

Class Observations. Two independent raters conducted class observations. Each year, raters attended six classes. In Fall 2014, they observed GAE class sessions and the parallel, content-matched class sessions that took place in the traditional class (overall 12 sessions). This procedure allowed the raters to compare the class sessions covering the same material but with differing teaching approaches (i.e., learner-centered vs. teacher-centered instruction). The two raters attended each class session together. Once in the class, the raters used a rubric to evaluate the class. In Fall 2014, raters used a rubric based on a previously constructed rubric that was created by the biology department for peer observations (http://extras.springer.com/ 2015/978-3-319-01651-1, in SM-Evaluation of teaching performance.pdf). In Fall 2015, to better document group work, the raters used the rubric developed by Shekhar and colleagues (2015).

Student Feedback. Students were invited to reflect on GAEs by providing anonymous written feedback on note cards following the activity. We use some of these data in the present study.

\section{Data Analysis}

Interviews were conducted by a science education researcher, audiotaped, and transcribed. A science education researcher and a doctoral student in counseling psychology separately analyzed the interviews and the note cards to define emergent themes. Then, they negotiated the findings until they could agree upon the themes (Maykut and Morehouse, 1994). The instructors were shown the interpretation of data to verify accuracy of interpretations. We present the results in accordance with the adapted Rogers (2003) model presented in Andrews and Lemons (2015). We slightly adapted the Andrews and Lemons (2015) model to the iterative process through which our instructors progressed to modify the course (see Figure 1).

\section{RESULTS}

\section{Motivation for Change}

Before 2014, the traditional BSCI207 class as taught was a three-credit course with three 50-minute lectures per week.

Alex described the traditional course:

Before the GAEs came into being, we taught in the very standard, traditional lecture. We used mostly PowerPoint to show text and images, occasionally we would bring a prop in, like sometimes I would bring a piece of a tree to gesture towards as I was lecturing about water transport or something like that. But it was basically standard lecture.

The instructors were dissatisfied with the traditional lecture format for the following reasons:

1. Evidence for inferiority of teacher-centered instruction compared with learner-centered teaching. The instructors expressed awareness of the empirical data documenting the superiority of learner-centered teaching over teacher-centered instruction, "There's a lot of research that suggests that [teachercentered instruction] may not be the best way to help the students understand what we're trying to get them to understand" (Alex).

2. Lecture hinders understanding of the process of science. The instructors also expressed a desire to get students to learn the process of science early in their education, rather than to passively receive information. "We are being asked as science professors more and more to try and get our students to understand that science is a process, earlier and earlier in their career, and to model what real science is like in their education" (Alex).

3. Lecture promotes overreliance on memorization. The instructors discussed a goal to modify the course so as to decrease focus on memorization and increase emphasis on problem solving and conceptual understanding. Julie described: "BSCI207 is the biology majors' class, and it's a lot of what the pre meds are taking, and so, critical thinking I think [is important], we're constantly trying to get them to not just memorize and regurgitate but to put the ideas together."

4. Breadth versus depth. The instructors were dissatisfied about the wide breadth of topics in the course and wished to move toward teaching fewer topics in greater depth. Julie described this shift: "We used to do lecture on the geologic record, and carbon 14 dating, and how you build the tree of life, and that is sort of all gone." The instructors also wished to reorganize the material more effectively into higher-order, meaningful concepts.

We also rearranged the material. So they [the lectures] used to be in a taxonomic orientation, I would give a whole lecture titled the biology of fungi, and the students complained that this taxonomic focus seemed to resemble the structure of BSCI106 [the prerequisite course]. I decided to explode those taxonomic lectures, and take the bits of content that I still thought were valuable, and spread them into other parts. So for example the stuff on mating types, which is wacky and interesting to me, and I hope to the students, is now in a lecture on sex. And they don't realize half the lecture is on fungi. So they're susceptible to packaging I think, and we don't get the complaint any more that the course is redundant to BSCI106 (Alex). 
5. Teacher-centered instruction hinders students' ability to perceive the interdisciplinary nature of material. The instructors commented that students tend to perceive disciplines as functioning in isolation, and they expressed their goal to increase students' understanding of interdisciplinarity. Alex noted,

Organisms don't care about our disciplinary boundaries of research. The organism doesn't understand that there's biophysics, and biochemistry, and evolutionary biology, and ecology, and genetics. All these attributes of their biology have to function simultaneously on several different spatial and temporal scales ... if we think they do, then we continually miss things that otherwise would fall out naturally if we were a little less wedded to our disciplines.

Relatedly, the instructors noted that most students enrolled in BSCI207 without having taken introductory physics or chemistry, which they thought was preventing students from drawing upon highly relevant concepts (e.g., thermodynamics) from these courses for biology.

6. Underrepresented groups do poorly in traditional classes. The instructors quantitatively examined student performance for specific student subgroups (i.e., underrepresented minority students, female students) in previous BSCI207 semesters. They observed that there were disproportionate D/F/W grades for underrepresented students. Coupled with the science education literature documenting the ability of active learning to help underrepresented groups (Preszler, 2009; Haak et al., 2011; Eddy and Hogan, 2014), the instructors speculated that adding active learning to the traditional class might help underrepresented students.

\section{Fall 2014}

In Fall 2014, the instructors went through the process of course revision that follows the adapted model by Rogers (2003) and Andrews and Lemons (2015; see Figure 1). In the following sections, we discuss their progression through the innovation-decision model. Table 1 shows a summary of the change process for the Fall 2014 semester.

Knowledge. Before the Fall 2014 semester, the instructors engaged in several efforts to increase knowledge about evidence-based teaching approaches to modify the course. The knowledge sources were as follows:

1. Consultation with discipline-based education research experts and FLCs. For example, Julie participated in a physics education FLC to learn about how students learn and to learn strategies to incorporate physics into biology (i.e., increase interdisciplinarity):

I will go ask [physics education professional] questions. When something doesn't go well I'll meet with the postdocs [from physics education research group (PERG)] over there and say, what are they not getting here, how can we make this better, so I'm always trying to get resources to help.

2. Reading the science education literature. As a new instructor, Julie participated in the college workshop for new instructors. The workshop was led by the director of the teaching and learning center, who provided several resources for using evidence-based teaching approaches, including an article giving an overview of learning styles (Felder, 1993), a book on teaching tips (McKeachie and Svinicki, 2006), and

TABLE 1. First Iteration of the instructors' change process

\begin{tabular}{|c|c|c|c|c|}
\hline & Knowledge & Decision/persuasion & Implementation & Reflection \\
\hline $\begin{array}{l}\text { Traditional (before Fall 2014) } \\
\rightarrow \text { traditional active } \\
\text { comparison (Fall 2014) }\end{array}$ & $\begin{array}{l}\text { 1. Consult with experts/ } \\
\text { FLCs } \\
\text { 2. Read science } \\
\text { education literature } \\
\text { 3. Observe other } \\
\text { instructors teaching }\end{array}$ & $\begin{array}{l}\text { Design an experiment to: } \\
\text { 1. Obtain evidence for } \\
\text { overall effectiveness } \\
\text { 2. Convince colleagues to } \\
\text { adopt active-learning } \\
\text { approaches } \\
\text { 3. Respond to grant award } \\
\text { requirements }\end{array}$ & $\begin{array}{l}\text { Fall } 2014 \\
\text { 1. GAE vs. traditional } \\
\text { format } \\
\text { a. Replace one lecture } \\
\text { per week with } \\
\sim 30 \text {-minute GAE: } \\
\text { ○ Use } 3 \text { TAs } \\
\text { during GAE } \\
\text { ○ Groups of } 3-5 \\
\text { students }\end{array}$ & $\begin{array}{l}\text { 1. Changed instructor role } \\
\text { 2. Content coverage } \\
\text { 3. GAE strengths } \\
\text { a. Engagement in } \\
\text { learning } \\
\text { b. Giving students } \\
\text { control } \\
\text { c. Modeling the } \\
\text { scientific process } \\
\text { 4. GAE weaknesses: } \\
\text { a. Disengagement } \\
\text { b. Insufficient time for } \\
\text { reflection } \\
\text { c. Student preparation } \\
\text { d. Assessments and } \\
\text { grading misaligned } \\
\text { e. Resistance to } \\
\text { learner-centered } \\
\text { activities } \\
\text { f. Group dysfunction } \\
\text { g. Auditorium chal- } \\
\text { h. Little impact on grade } \\
\text { distributions } \\
\text { TA training required }\end{array}$ \\
\hline
\end{tabular}


the book Scientific Teaching (Handelsman et al., 2007). In her interview, Julie commented, "So I read a lot of books,... I think it was getting students to think about math, I read one of the books [that the director of the college teaching and learning center] had given me [Scientific Teaching]."

3. Observing other instructors teaching. The instructors had observed another instructor who implemented evidencebased teaching approaches in a small class of BSCI207 (<40 students). This pilot implementation was successful, and the instructors were interested in investigating whether the learner-centered teaching model used could be scaled up to a large-enrollment class.

Persuasion/Decision. Following the knowledge-generation phase, the instructors felt prepared to change their teaching to a more learner-centered teaching style. They decided to conduct a comparative experiment during the first implementation of the GAEs (i.e., traditional vs. GAE classes; see Marbach-Ad et al., in press, 2017). Although the instructors were aware of the literature documenting the effectiveness of learner-centered teaching, they had several reasons to execute the experiment:

1. Obtain evidence for overall effectiveness. The instructors were unsure whether their activities were the best way to change the course (e.g., they were unsure of the challenges that would emerge, how the intervention would impact students). The instructors also wished to explore cost-effectiveness, since they knew that changing the course would require a high instructor time commitment.

2. Convince colleagues to adopt learner-centered teaching approaches. The instructors noted that faculty in the department were unconvinced of the superiority of learner-centered teaching approaches, and they thought that a comparison study bringing empirical evidence might demonstrate that changing one's teaching style is worthwhile. Alex stated, "[A] lot of my motivation for this experiment was to try to provide some evidence that these approaches were worth the effort, and because there is resistance clearly, from some of our colleagues who have been teaching the course for a long time."

3. Respond to grant award requirements. As mentioned earlier, the institution announced a call for proposals for instructors to revise their teaching. The instructions required applicants to propose comparative experiments during course revision to document effectiveness.

Implementation. As proposed in the provost grant application, the instructors executed the comparison study. In the traditional class, instructors delivered a 50-minute lecture three times per week. In the GAE class, one lecture was replaced with a GAE. The GAE consisted of a brief 20-minute introductory lecture (a short version of the lecture presented to traditional class students) and a 30-minute group activity. As scientists, the instructors wished to manipulate the addition of the GAE day only and to keep remaining variables constant across classes. Therefore, homework assignments, examinations, optional computer tutorials, and office hours availability were consistent in both classes (see Table 2).

In the GAE class, on the day of the GAEs, students were instructed to sit with groups of three to five students (of their own choosing) and to leave empty rows between groups.
TABLE 2. Fall 2014 class comparison

\begin{tabular}{lll}
\hline Weekly class sessions & GAE class & Traditional class \\
\hline Weekly homework session and & Three lectures \\
Tutorials & $\begin{array}{c}\text { Homework problems } \\
\text { graded for effort } \\
\text { Optional }\end{array}$ & $\begin{array}{c}\text { Homework problems } \\
\text { graded for effort } \\
\text { Optional }\end{array}$ \\
TAs & Four GTAs & Four GTAs \\
Assessments & 136 students & 198 students \\
Room setting & Pretest, three tests, & Pretest, three tests, \\
& final exam & final exam \\
\end{tabular}

Students were asked to have at least one laptop per group. As discussed previously, the GAEs were designed to be more learner centered relative to traditional lecture classes. To illustrate this here, we give Alex's description of the membrane transport GAE: "The students had a little computer simulation, and they used that to generate data that they then entered into a Google docs spreadsheet in real time in the class, and there were enough students in the class that their responses produced this beautiful textbook plot of transport rate versus concentration. They built that relationship in a way that otherwise I would have just told them."

Reflection. Following the Fall 2014 semester, the instructors reflected on the various pros and cons of the learner-centered teaching intervention in the interviews. Observers and students also provided feedback that was used by the instructors to reflect on both sections of the course and on the comparative experiment. Several themes emerged from these data:

1. Changed role of the instructor. The instructors described how the role of the instructor changes from someone who lectures the students to someone who facilitates and advises the students during their learning process. Alex noted, "When you hand the class over to the class, for the active exercises, you become more of an advisor, and less of a performer." Julie similarly stated,

It's much less about my spouting facts, it's about my thinking ahead of time to get them to draw conclusions and get them to cement ideas. My role was partly just to control the chaos sometimes, and to control that the TAs had the information they needed so they could provide guidance to the students.

Importantly, observers noted that the instructors were very actively engaged with student groups throughout the GAEs, helping students to work through problems and understand concepts. Julie also commented that teaching with GAEs requires greater proficiency with material than lecturing: "To use these activities, you have to know the material better than if you're going to straight lecture. And I think some instructors are maybe still learning BSCI207, what is all the material in it. And until you teach it straight a couple of times you probably don't have the background to really understand."

2. Content coverage. The instructors felt that they needed to make compromises in order to implement GAEs. That is, in order to gain the class time for GAEs, they needed to sacrifice 
lecture time and reduce the coverage of course topics. This was not easy for them, especially in light of the function of BSCI207 as a prerequisite and preparation course for the Medical College Admission Test (MCAT). Julie described examples of reductions in content coverage:

We spent less time talking about dating the origins of life using various methods (fossil record, carbon dating); we got rid of a lecture on prokaryotes and had to shrink some of the nutrient assimilation information from two lectures to one.

The instructors explained that, in order to minimize loss of content coverage, they decided to have a GAE class only once per week and to pick GAEs corresponding to lecture topics for which "there was the least amount of lost material by focusing on a particular exercise" (Alex). An additional solution was to move in-class lectures to online, preclass lectures. Julie described this change: "We also ask students to review some of the material that is lost during lecture time into the prep slides they review ahead of time." However, Julie wondered whether students would benefit from online lectures to the same degree as in-person lectures: "I am still worried they don't get so much out of those [online lectures] and so miss much of that information."

\section{GAE strengths}

a. Engagement in learning. Overall, the instructors reflected that most GAEs provided a space for students to interact with one another, TAs, and instructors: Julie added, "I think it was nice to see the energy in the class and the way the students took to the activities, it was different for them." Observers noted that the GAE class treatment condition was usually associated with increased student interactivity. Specifically, they noted that students in the GAE class were not only more engaged in the GAEs, but that they also tended to raise more questions during the PowerPoint presentations relative to students in the traditional class. Students reflected on their note cards following GAEs, and in the end-of-semester survey, noting that they felt that many of the GAEs were engaging (see Marbach-Ad et al., in press, 2017).

b. Giving students control over learning. The instructors noted, "The GAEs represented a chance to turn the class over to the students for some part of the time, where they could do something actively, instead of just sitting there listening to us" (Alex).

c. Modeling the scientific process. The instructors were also pleased with how the GAE provided an opportunity for students to more closely experience the scientific process in the classroom relative to traditional lecture. Alex described how the GAEs gave the students an opportunity to take an active role in their learning:

It's actually a bit more how real science works, right, even as somebody who runs a lab, I don't go into my lab and sit there and talk to my graduate students for four hours, I mean we have a brief conversation about how they should tackle something, and then they go off and work more on it. So it's more of a checking in and then separating again. That's kind of how this class works, the GAEs do give the students a little more of a feel of how collaborative real science works, and how no one person is sort of dictating everything, everyone needs to be a bit independent. ... I think that this active model gives the students, for the first time, a real taste of how a real scientist would approach a problem.

Students commented on the opportunity afforded by GAEs to take an active role in their learning: "I learned how to apply what we learn in lecture class to actual problems"; "I kind of felt like a real scientist since I was put in a situation in which I had to make a hypothesis myself."

4. GAE weaknesses. The instructors and observers noted that some activities needed to be modified substantially for the following reasons:

a. Disengagement. The instructors noted that, for some GAEs, students were disengaged. For example, in the GAE on stress and strain, two students were doing measurements in front of the class for 10-15 minutes, and the remaining students were instructed to input data into Excel files. These data were then used to make calculations. Students also expressed their dissatisfaction with this activity on the note cards that they handed in to the instructors: "I feel I understood the concept well once Dr. Julie wrote the plots on the board. This activity was more tedious and like busy work"; "We could have easily compared values without experimentally finding them. I didn't feel this deepened my understanding of concepts."

b. Insufficient time for reflection. The instructors noted that most exercises were too long, which did not leave sufficient time for reflection. Alex noted, "Well I think also making sure that if we get the exercise done in the right, short amount of time, then that does give us time to add a reflection at the end. Connecting the results of our exercise back to some larger idea."

c. Student preparation. The instructors felt that students would gain more from the exercise, if they were to come to GAE classes with better understanding of concepts relevant to the GAE. Then, more time could also be allotted for summary and reflection on important concepts. Alex commented, "We probably will need the students to do a bit of preparation before they come in to these active exercises, so that we can spend less time setting it up, and more time summing it up."

d. Assessments and grading misaligned with GAEs. In this implementation, instructors kept the same assessment plan for both the traditional class and the GAE class in order to compare achievement across classes. This resulted in a mismatch between the course activities and the assessments in the GAE section. For example, there were no final examination questions specifically covering GAE material. Of note, the instructors analyzed their final examination questions before conducting the experiment and saw that the questions required students to demonstrate high levels of thinking (Bloom and Krathwohl, 1956; e.g., knowledge application, quantitative analysis), and they believed the GAEs would improve students' abilities in these areas. Further, the instructors did not count GAE participation toward final grades, which instructors and observers believed had a detrimental effect on GAE attendance. Julie 
noted that "on the GAE days, only $60 \%$ of the students would come. That was partly because they wouldn't get any credit for it, and they weren't seeing that it was helping them learn the material better." Analyses showed that students with higher grade point averages (GPAs) were those who chose to attend on the GAE days (see Marbach-Ad et al., in press, 2017). Given this, the instructors felt that attendance should be incentivized in future implementations of the learner-centered teaching intervention to motivate and benefit a wider range of students.

e. Resistance to learner-centered activities. The instructors felt that students' low attendance specifically on GAE days may also have been because the students did not perceive the benefit of GAEs for their learning. "I feel sort of parental here, maybe the GAEs are like broccoli and brussels sprouts, they need them, they just don't know it yet" (Alex).

f. Group dysfunction. The instructors and observers noted several issues with the groups. Some groups were not engaged, and some students were not participating within their groups (e.g., one student would be left out). In some activities, some groups would finish the activity very quickly and would subsequently appear bored and waiting for further summary or instruction. Julie was frustrated with these occurrences and noted, "People would be sitting there on their phones." One reason for student disengagement could be that students groups were unassigned and could include different students each week: students "would sit and associate with whoever was around them" (Julie).

g. Auditorium-setting challenges. The instructors commented on the difficulty of doing GAEs in the large auditorium: "It's still tricky to think about how you actually stage all of this, there is a bit of theater to running a large class with 200 students, how you move from one aspect of the process to another [lecture to group activities] quickly, without losing people, without too much noise and disturbance" (Alex).

h. Little impact on grade distributions. Alex and Julie were hopeful that the GAEs would lead to large improvements in students' grades as compared with traditional learning. However, the effect of GAEs was very small. Alex commented, "This was the biggest outcome from my perspective, and it drove much of the revisions for 2015. This is interesting, as it shows that even though we were unable to realize a big payoff in the first year, we nevertheless saw something that we thought was worth keeping and hopefully improving upon."

5. TA training required. The instructors reflected that they did not provide adequate TA preparation for the GAEs: "We hadn't really prepared the GAEs enough ahead of time so that we could talk about them with the TAs. The TAs at times were really clueless about what was supposed to be happening" (Julie). TAs, although instructed to guide and facilitate groups, apparently lacked the skills to engage students, as observers noted that most of them passively waited for students to ask questions rather than actively approaching students with questions, instructions, etc.

\section{Fall 2015}

On the basis of their reflection, Julie and Alex decided to continue teaching with GAEs and to seek new knowledge to improve GAEs. In the following sections, we discuss their continued progression through the innovation-decision model (see Figure 1). A summary of the change process in Fall 2015 is shown in Table 3.

\section{Knowledge}

1. Learn about methods to form successful groups. The instructors reviewed the literature and consulted with the director of the teaching and learning center and other faculty members in the department to form new strategies on building effective groups in auditorium settings. The literature shows that groups work best when they are permanent and students are held accountable to other group members (Michaelsen and Black, 1994; Michaelsen et al., 2004, 2008). The literature also shows that taking student diversity into account is important in creating successful groups (Watson et al., 1993). For example, Watson and colleagues (1993) reported that, although it takes time, heterogeneous groups outperformed homogeneous groups on several performance measures, including generating perspectives and alternative solutions. The instructors also learned from the director of the teaching and learning center about the Pogil method (pogil.org), in which students are assigned different roles during group work (e.g., recorder, facilitator). They weighed the pros and cons of implementing this method in the classroom.

2. Learn about methods to flip courses. The instructors learned from models of flipped classes (Hamdan et al., 2013; Jensen et al., 2015), which highlight how to capitalize on

TABLE 3. Second iteration of the instructors' change process

\begin{tabular}{|c|c|c|c|c|}
\hline & Knowledge & Decision/persuasion & Implementation & Reflection \\
\hline $\begin{array}{l}\text { Traditional GAE comparison } \\
\quad \text { (Fall 2014) } \rightarrow \text { GAE only } \\
\quad \text { (Fall 2015) }\end{array}$ & $\begin{array}{l}\text { 1. Learn about methods to } \\
\text { form successful groups } \\
\text { 2. Learn about methods to } \\
\text { flip courses } \\
\text { 3. Seek expert guidance } \\
\text { 4. Learn about strategies to } \\
\text { enhance TA support }\end{array}$ & $\begin{array}{l}\text { 1. Teach all sections with } \\
\text { learner-centered } \\
\text { teaching } \\
\text { 2. Modify the GAEs } \\
\text { 3. Develop preparation } \\
\text { activities } \\
\text { 4. Better train the TAs and } \\
\text { add ULAs } \\
\text { 5. Revise group structure }\end{array}$ & $\begin{array}{l}\text { Fall } 2015 \\
\text { 1. Modify activities } \\
\text { 2. Revise group setting } \\
\text { 3. Add more and } \\
\text { better-trained TAs }\end{array}$ & $\begin{array}{l}\text { 1. Student preparation } \\
\text { 2. Student attendance } \\
\text { 3. GAE revision } \\
\text { a. Mechanics of } \\
\text { exercises } \\
\text { b. Allocating time for } \\
\text { reflection } \\
\text { c. Technical issues } \\
\text { 4. Group functioning } \\
\text { 5. TA and ULA } \\
\text { contributions }\end{array}$ \\
\hline
\end{tabular}


out-of-class time to cover material to prepare for face-toface active learning. In this regard, instructors sought assistance from the information technology office about presentation software (i.e., Camtasia) that can deliver automated lectures effectively.

3. Seek expert guidance. During the summer, the instructors again consulted with science education experts to enhance the GAEs. For example, they consulted with a science education expert on how to revise the concept map assignment. Julie described how this guidance helped her "leave the activity a bit more free form and get the students to make a graphic organizer of their own design rather than trying to fill in some pre-designed boxes." As another example, the science educator recommended strategies about how to streamline GAEs to maximize time spent on developing conceptual understanding and minimize time spent on the mechanics of exercises.

4. Learn about strategies to enhance TA support. The instructors wished to decrease student to TA ratio. However, GTAs require departmental funding, which was unavailable. The teaching and learning center director and the biological sciences administration offered to involve ULAs who are unpaid but receive alternative benefits, such as leadership and teaching experience and undergraduate course credit. This model was reported to be successful in our university (Schalk et al., 2009) and in other institutions (Otero et al., 2010).

Persuasion/Decision. Following reflection on the comparative experiment, instructors sought to keep improving the course and decided to make several changes:

1. Teach all sections with learner-centered teaching. Although the instructors reported that keeping the GAE class format requires more time to prepare relative to lecturing and takes time from their research ("fine tuning the GAEs-that took weeks" [Julie]), they decided to implement the GAEs in all sections and to work to improve them.

2. Modify the GAEs. The instructors decided to revise some of the GAE activities. For example, Julie reflected that, since the GAE covering stress and strain failed to sufficiently engage students and did not allow time to focus on higher-level concepts, she decided to change the nature of the activity:

[Last semester] I had a couple of students up front doing the experiment, and everyone else was kind of twiddling their thumbs while we gathered the data. We talked about the data but we didn't really have time [to do data analysis and summarize concepts]. I think this year I'm just going to give them last year's data, and have each group do some analysis.

As another way to modify GAEs, instructors decided to utilize more outside resources such as published, case-based activities. Julie described, "I'd love to come up with some more case studies that we could do. You know the Buffalo site [http://sciencecases.lib.buffalo.edu/cs/collection] has all the case studies for all the science classes. So I'm constantly perusing that. A couple of the GAEs that I developed actually come from there."

3. Develop preparation activities. To make GAEs more learner centered, Julie and Alex decided to move the introductory lecture content used in 2014 to an online, preclass preparation exercise. This preclass preparation took the form of online lectures, YouTube videos, and reading assignments. Julie described the process of trying to improve delivery of content to students online:

I haven't figured out what the best prep work is. What Alex has been doing is taking the slides he showed last year and just posting them online. I'm not sure that's the best, or really enough.... But, then they just read. I mean he tries to put more words on them. I tried to find some videos that I thought were appropriate, and I'm not sure that's any better. I was going to do some of these with Camtasia. In this way you can actually have the slides and actually talk over them and record. But I couldn't make the software work. I haven't really gone there yet, I will have to figure that out.

To encourage students to prepare for the GAEs, the instructors decided to give a preclass quiz covering the out-of-class preparatory materials. Julie described,

We're also doing a quiz this time, we're giving that preparatory information, they have to have done it by the morning before, they have to take a little 2-point quiz [before class] to show that they've covered that material. Then we have the whole class time [for the GAE] so that we're not so rushed in trying to do to many things at one time.

4. Train the TAs better, add ULAs, and involve both teams in the process of GAE development. The instructors decided to expand the team of assistants to decrease the ratio between students and TAs. Julie described the change from Fall 2014 to Fall 2015: "We have a bigger team. We have two of these ULAs, and then we have three UTAs, and two GTAs. So a team of seven helpers, and each person has a different job. The ULAs are specifically supposed to be trying out the GAEs ahead of time. So we kind of run things past them. And then we meet with all the TAs, and then talk through the GAEs beforehand. They have an assigned part of the class, where each of them is hopefully seeing the same students over and over, and hopefully getting to work with them to develop a rapport, and they go in the middle of the activity, so kind of checking in, so what do you think, kind of getting students to verbalize." The benefit of this new format, where each TA was responsible for a subsection of the large class, was that it approximated a smaller class discussion session in which students could get to know their TAs more personally.

5. Revise group structure. On the basis of the literature and their previous experiences, the instructors decided to assign permanent, diverse groups of four at the beginning of the semester. They also decided to instruct students on how to sit in the auditorium with their groups (in two rows rather than in a single line, to enhance group communication) and to award points for completing group work exercises.

Implementation. In the Fall 2015 implementation, there were several changes to the course (for a comparison of 2014 and 2015 GAE classes, see Table 4).

1. Modify the activities. The instructors devoted a full weekly class period to the GAE instead of 30 minutes. On the basis 
TABLE 4. GAE class comparison between Fall 2014 and Fall 2015

\begin{tabular}{|c|c|c|}
\hline & GAE class (2014) & GAE class (2015) \\
\hline Preparation & $\begin{array}{l}\text { In-class lecture } \\
(\sim 20 \text { minutes }) \\
\text { before GAE }\end{array}$ & $\begin{array}{l}\text { Online lecture slides + } \\
\text { graded, preclass quiz }\end{array}$ \\
\hline Homework & $\begin{array}{l}\text { - Homework } \\
\text { problems graded for } \\
\text { effort }\end{array}$ & $\begin{array}{l}\text { - Homework problems } \\
\text { graded for effort }\end{array}$ \\
\hline Activity duration & - $\quad \sim 30$ minutes & - 50-minute class period \\
\hline TAs & - Four GTAs & $\begin{array}{l}\text { Two ULAs, three } \\
\text { undergraduate TAs, two } \\
\text { GTAs (seven total } \\
\text { helpers) }\end{array}$ \\
\hline Exams & $\begin{array}{l}\text { Exams did not } \\
\text { include specific } \\
\text { questions from GAE }\end{array}$ & $\begin{array}{l}\text { Exams included } \\
\text { questions from GAEs }\end{array}$ \\
\hline \multirow[t]{2}{*}{ Grading } & $\begin{array}{l}\text { - Homework } \\
\text { assignments }\end{array}$ & - Homework assignments \\
\hline & - Exams & $\begin{array}{l}\text { - } \text { Prequiz } \\
\text { - } \text { GAEs } \\
\text { - Exams }\end{array}$ \\
\hline \multirow[t]{3}{*}{ Student groups } & $\begin{array}{l}\text { - Not assigned/ } \\
\text { impermanent }\end{array}$ & - Assigned/permanent \\
\hline & $\begin{array}{l}\text { Three to five } \\
\text { students }\end{array}$ & - Four students \\
\hline & $\begin{array}{l}\text { - Free auditorium } \\
\text { seating }\end{array}$ & $\begin{array}{l}\text { - Specific auditorium } \\
\text { seating }\end{array}$ \\
\hline
\end{tabular}

of their experiences in the previous semester, they revised some GAEs and adapted them to the time frame. Although they had more time for the GAEs, they wished to make them more efficient and interactive: "I think we had to cut some, with the GAEs, because they were taking way too long, but I think in a few cases we simplified them, took out $1 / 3$ of them or something" (Alex). Instead of the 20-minute preGAE lecture that was presented in the Fall 2014 implementation, students were asked to prepare for activities at home by watching videos, reviewing lecture slides, and reading textbook materials. In contrast with Fall 2014, the students were awarded three points for participating in the GAE activity and two points for completing a quiz covering preparatory materials that was due before the GAE class. The instructors wished to assign points to these activities in order to "really give them weight" (Julie). "[The activities] formed a large part of the exams as well. So making the activities more integral to the class was a big change" (Julie).

2. Revise group setting. In Fall 2015, the instructors created permanent groups that were diverse with regard to prior scholastic achievement (based on an average of GPA and Scholastic Aptitude Test scores) and demographics. Julie described the process of delineating the groups before the semester began: "We went through and we divided the groups into scholastically top, middle and bottom, and unknown, because we didn't have data for some students. So we had one student from each of those four groups, or divisions, and then I went though and I sorted them all by if they were women or minorities, and I tried to make each group such that there were at least two minorities, or at least two women, so there wouldn't be isolation of an individual member in the group.... It was a big pain to do." Alex added that he thought "it was worth the effort, because random, free association would lead to random self-sorting that wouldn't help the group as a whole." Julie described that one of the challenges with the student groups, although seemingly a small detail, was the seating arrangement: in the prior semester, groups of three to five students would sit together in a row, and in many cases, the two students on the ends would be left out. To attempt to remedy this, she described:

So the next time I drew a map in the room, [which showed] two students in the front, and two students in the back. When you have a very formal auditorium, you have to try and help them assort with each other and talk with each other. The other thing we did was, we were giving each group two copies of the assignment, so they didn't each have one. So that kind of helped, that kind of had them sharing things.

Finally, TAs and ULAs were assigned to stay with one section of the lecture hall throughout the semester. Thus, TAs and ULAs developed a rapport with a large group of students throughout the semester and were able to learn their names, which facilitated communication.

3. Add more and better-trained TAs. Before Fall 2015, the instructors trained the TAs to better engage with student groups in class. Class observation data showed that, in Fall 2014, some TAs were lacking in their ability to engage actively with students. One observer described, "When I observed the classes last year [Fall 2014], they [TAs] were standing in the side [of the auditorium], and sometimes they got to students, but just students that raised their hands. They weren't active. They were very passive, most of them, because they didn't know what to do." Following the implementation in Fall 2015, the observer noticed a change in TA involvement: "Now, it's more about instruction, they circulate between groups and encourage them to ask questions, they encourage students that aren't participating ... it's not enough to throw them [the TAs] in the classroom."

Reflection. Overall, instructors noticed improvements in the areas that they targeted to improve, and they also felt there were areas that they wished to continue improving.

1. Student preparation. Julie described that although new techniques were put in place to increase student preparation, students often seemed unprepared for the activities: "And my data for that is essentially for the first 20 minutes of the GAE they would spend saying, what are we doing? There was a lot of flailing. It took them a lot longer to get going with the GAE than I thought, and I'm not sure if that's because the preparatory material is not really preparing them, or that they just took the online quiz and didn't really go through the preparatory material." Julie thought about changing the nature of the preparatory lectures, "I would still like to explore turning those into little online lectures rather than having them read the slides."

2. Student attendance. Alex commented that the strategy of assigning points to participating in GAEs "made a big difference in attendance [...] by incentivizing their attendance, at 
least on GAE days, they were coming." The instructors commented that incentivizing participation in the GAEs and the preactivity quizzes increased the amount of student-instructor interaction regarding point grabbing. Alex stated, "The downside of associating points with everything is that I think we spent the largest fraction of our student interaction time dealing with the points related to the GAEs, excused absences, non-excused absences, anxiety about the points, I mean these are tiny amounts of points, but the students took it very seriously. But I think it was one of the top 3 issues that students came up with this semester."

\section{GAE revision}

a. Mechanics of exercises. Julie was very frustrated with how students could not effectively operate Excel software: "And they still don't know Excel. My biggest frustration was that I thought Excel would make their lives easier, and it made their lives harder. I'm almost ready to go back to pencil and paper, just to get them to plot things and think about things, because they're not getting back to the scientific inquiry and hard thinking, they're just so stuck in which box do I click." Alex added, "My issue is that the preparatory materials do a good job preparing them intellectually for what's the point, but then they do get stuck on the mechanics, what they're doing with their hands."

b. Allocating time for reflection. The instructors described that they improved substantially in the area of summarizing major concepts and timing activities: "I think we did a pretty good job of every 15 or 20 minutes bringing them back together and saying ok, you would have done this by now. There were a couple that worked really well, and a couple where we were still pressed for time. I think that generally it was far improved" (Julie). Because the instructors had the full class period to devote to the GAE and did not need to compare learner-centered teaching with teacher-centered instruction, they felt that the timing of the activities was much improved. Julie noted, however, "I always overestimate what students can do. I'm still adjusting."

c. Technical issues. There were difficulties with connecting to the wireless Internet in the lecture hall, particularly among students who failed to download the appropriate tools before coming to class. Further, students have different types of computers and software programs and knowledge of software programs required for the course.

4. Group functioning. Overall, the instructors were satisfied with the permanent and diverse groups they had created, noting that they were "pretty happy actually with how the groups functioned" (Julie). Jason, the GSS undergraduate student, described how the new group setting encouraged group work beyond the classroom and facilitated a sense of community:

The organized approach helped students see the material as well as make a few friends, in fact, I remember coming onto my dorm floor and seeing four people from my class working together, and they were actually in that GAE group, they had made a study group because they were used to working together. One of the aims of this project gets students communicating instead of competing.
Julie commented that there is still room for improvement in the student groups: "I saw a number of groups where at least one person would be left out. I don't know if that's a physical orientation, if we could point them toward each other it would be better. Next year one thing we talked about is going to groups of 3 , because with 3 you can always get across each other and be more ... everybody can talk to each other." The instructors considered the benefits of the Pogil. Julie explained that they tried to appoint a different group member to act as the scribe each week during GAE activities as a way to increase student participation in groups. The instructors did not strictly enforce this policy, as they were not sure it was beneficial.

5. TA and ULA contributions. Julie commented, "I think they worked really well. So we kind of divided everybody's tasks, so the ULAs were the ones that we would send the GAEs to get their input back, and one was probably better than the other at that, and they were in charge of grading the GAEs.... So they had their own little world that they dealt with in that. Both ULAs and GTAs I think participated in the GAE facilitation, and then all of the grading, and the lecture." Lisa, one of the GTAs, described how the faculty and TAs worked as a team to plan GAEs, "Each week we would have a TA faculty meeting, and we would talk about the upcoming GAE meeting, sometimes a week in advance, sometimes a little bit more. And they would talk about the materials, and we would have time outside of the meeting to read over and suggest changes." She also emphasized how they encouraged input from the ULAs:

And we also had some undergraduates this year, ... and I think they were really helpful because they understand what the students are capable of, more than we do ... a lot of times they can give you some insight into what's going on or what classes undergraduates are most likely taking at the same time. It was very helpful.

Finally, Lisa felt that the level of engagement among the teaching staff was higher than for a standard lecture course: "Everyone was very engaged, it's a unique class to TA for, because I feel like the TAs and the professors are far more engaged than in a standard lecture course, so it was kind of nice." Alex reflected that, in the future, "It would be even better," since they will have "a whole floor of ULAs that had us for 207," and they "will be well-positioned" to assist in the redesigned course.

\section{DISCUSSION}

This case study examines instructor change processes when moving from teacher-centered instruction toward learner-centered teaching. In this study, we examined the change process through the lens of the innovation-decision model (Rogers, 2003; Andrews and Lemons, 2015), which recognizes several stages of change: knowledge, decision/persuasion, implementation, and reflection. The model is iterative, recognizing that transforming courses may require multiple revisions as instructors reflect on the inherent challenges and imperfections that arise when changing a course (Henderson, 2005). Consistent with this literature, the first implementation of learner-centered course revision was fraught with imperfections, and the 
instructors persisted through two rounds of course revision before gaining satisfaction with their teaching approach, although they plan to continue enhancing the course with each semester.

Andrews and Lemons (2015) note that dissatisfaction with one's current teaching approach is an important motivator leading instructors to change their teaching. Our instructors were dissatisfied with the lecture mode of teaching in their courses due to personal dislike for it, and the sense that it encouraged student reliance on memorization and hindered interdisciplinary thinking. Other motivators for change included 1) awareness of national recommendations to use learner-centered teaching (AAAS, 2011); 2) a hope that underrepresented students would benefit from learner-centered instruction, based on education literature documenting such benefits (Okebukola, 1986; Seymour and Hewitt, 1997); and 3) institutional support (i.e., a provost office grant initiative).

These motivations led the instructors to seek new knowledge about learner-centered teaching approaches and how to implement them, which, according to the adapted innovationdecision model (Andrews and Lemons, 2015), is a first step toward changing a biology course. In the present study, knowledge-seeking strategies included consultation with science education experts and information technology experts, reading the empirical literature, observing other faculty members who had adopted evidence-based teaching practices, and involvement with a discipline-based FLC. Following the knowledge stage, the instructors progressed through the decision/ persuasion and implementation stages of change. In the reflection stage, the instructors discussed what worked well, challenges, and areas they wished to improve in the subsequent iteration. We present here implications from this study for instructors seeking to change their courses, and also for administrators wishing to promote learner-centered instruction at their institutions.

\section{IMPLICATIONS FOR INSTRUCTORS}

Weimer (2013) noted that engaging students in their own learning is messy, unpredictable, and challenging as compared with teacher-centered instruction. The process can be difficult for the faculty members who want to change as well as for the students. First, the instructor must adopt a new role as "instructor-facilitator" (Weimer, 2013), giving up a degree of control to the students to take responsibility for their own learning. Relating to their new role, our instructors reported that, on the one hand, the instructor-facilitator role felt like controlling chaos at times, particularly in the beginning, but that it was markedly beneficial for student learning and for their own teaching. For instance, it gave students an opportunity to be independent learners and to engage with their peers in collaborative problem solving, more closely modeling the process of science. Thus, although it may be intimidating to share control over the learning process with students, it appears that there are benefits for both students and instructors.

Second, learner-centered teaching encourages instructors to cover fewer topics in greater depth, as opposed to more topics in less depth (Weimer, 2013). Despite being uncomfortable with losing content coverage due to the function of BSCI207 as a preparation course for the MCAT and a prerequisite, our instructors decided to remove some course topics and consoli- date others into shorter units. Next, they implemented several solutions to the necessary loss of content coverage. First, they moved lecture content to required preclass, online lectures that substituted for in-class content coverage. Second, they were strategic about which course topics they used to redesign as GAEs. Specifically, they selected course topics that were historically conceptually challenging for students (e.g., membrane transport). Our faculty members' transition process provides an example of how faculty members can identify and implement solutions for concerns about loss of content coverage.

Third, a fundamental principle of learner-centered teaching is to encourage collaboration in the classroom (Weimer, 2013). To this end, our instructors implemented GAEs, a series of group work-based activities. Student collaboration is important, because it promotes sharing of the learning agenda (Johnson et al., 1984; Weimer, 2013), and collaboration is a skill that is essential for the workplace (Hart Research Associates, 2015). Group work is a common and accessible strategy that instructors can use to increase learner-centered teaching in their classrooms. Our instructors experienced various challenges and implemented several revisions to group work activities throughout their change process. The most successful strategies for optimizing group work included 1) increasing the number of TAs and the amount of TA training; 2) creating diverse and permanent student groups to increase accountability (Michaelsen et al., 2004); 3) assigning grades and preparation assignments for group work activities; and 4) restructuring group work activities to provide more time for whole-class summary and reflection on concepts. Group work is just one type of teaching strategy that can increase learner-centered teaching. Each instructor needs to discover what kinds of approaches are most suitable to increase their level of learner-centered teaching. When selecting and implementing new teaching strategies, it is highly recommended to seek guidance from experts, more experienced faculty members, or from a teaching and learning community.

Transitioning away from lecture-based instruction to learner-centered instruction can be challenging for students as well as instructors. The literature has shown that students resist many learner-centered approaches that require them to engage in the classroom rather than sit anonymously in lecture (Michaelsen et al., 2008; Shekhar et al., 2015). Our instructors learned about student resistance through several means: 1) student feedback that was collected on note cards at the end of GAE classes, 2) end-of-semester surveys asking students to reflect on each activity, and 3) low attendance on GAE days as compared with lecture class days. It is important for instructors transitioning their courses to monitor student resistance and satisfaction, as our instructors used these data to modify the activities from the first to second iteration.

The instructors used several strategies to reduce student resistance. First, through student feedback, instructors learned that they needed to provide students with better explanations for the purpose of doing GAEs as opposed to sitting in lecture class. Weimer (2013) emphasizes the importance of providing students explicit instruction on how to best learn. Therefore, at the second iteration of the learner-centered implementation, the instructors were explicit about the rationale for the GAEs. At various points throughout the semester, the instructors explained how the GAEs were helpful in enhancing skills 
(e.g., critical thinking, problem solving, collaboration, understanding the interdisciplinary nature of science, relating course material to everyday life and to scientific research) that are recommended by national organizations (AAAS, 2011) and employers (Hart Research Associates, 2015). Second, instructors awarded class participation points for completing GAE exercises and grades for completing the preclass online quiz. This strategy resulted in better alignment between requirements of students and course assessments, which accords with Wiggins and McTighe's (2005) backward design theory. This method of GAE grading resulted in much higher student attendance as compared with the first iteration. Third, instructors used evidence-based strategies to reduce resistance within student groups, including creating permanent, diverse groups at the start of the semester. Fourth, instructors took student feedback into account with regard to their satisfaction with specific activities and modified activities with the goal of maximizing student engagement.

\section{IMPLICATIONS FOR ADMINISTRATORS}

Given that changing one's teaching from teacher-centered instruction to learner-centered teaching is challenging, there must be administrative support for these efforts.

First, administrators can play a key role in acknowledging the importance of learner-centered teaching. Historically, universities have failed to encourage faculty members to prioritize teaching to a similar degree as research (Fairweather et al., 1996). Unfortunately, many tenure-track faculty members at research-intensive universities fear that they may be penalized for investing the time to adopt learner-centered teaching. Research-oriented universities should prioritize teaching in order to support more widespread adoption of evidence-based teaching approaches. Julie reflected on her frustration with the university's message that teaching is devalued relative to research:

I think for assistant professors, I was actually scolded for putting time into teaching and trying to participate in teaching improvements and so, I think it's discouraged, perhaps rightly so, because they're not going to value it, so if that's going to take away from what's required to get tenure, to get promoted, they want you to know that. So they're just being honest perhaps.

As part of a university culture that values learner-centered teaching, administrators (e.g., chairs, promotion committees) should acknowledge instructors who are making the effort to transition their courses and understand if their teaching evaluations are lower during the initial semesters of transition.

Second, as evidenced by our study and by others in the literature, transitioning from lecture-based teaching to learner-centered teaching requires a large time commitment from instructors. Thus, funding and release time are valuable supports that administrators can provide to improve the quality of teaching at their institutions. The provost grant was a fundamental support contributing to our instructors' success in transitioning a core biology course. Further, the fact that teaching fellowships were awarded from the university provost shows that our research-intensive university is beginning to value faculty members' adoption of learner-centered teaching. Alex commented on these fellowships:
The message comes through that the university values teaching, otherwise we wouldn't have these fellowships from the Provost, that's about as high up as it gets, I mean there is this signal, a voice that says, great, please do this. But then when the rubber meets the road, are you going to get promoted? It is not considered a substitute for quality research productivity as a research-active faculty.

Third, learner-centered instruction requires more human resources relative to teacher-centered instruction (e.g., for grading, facilitating small-group discussions, demonstrations, assisting in revising course activities). Administrators should consider ways to assign more TAs to courses that use learner-centered teaching. TAs and/or ULAs could be compensated through financial means or through other methods like course credit. Our university, for example, has developed a training program for undergraduate TAs, in which they receive training in how to facilitate small groups.

Fourth, in universities where there are state-of-the art facilities for teaching and learning, there should be a priority for courses that adopt innovative teaching approaches. In our university, such facilities are in a state of development, and administrators are planning to incentivize faculty who are using evidence-based teaching approaches by giving them priority to teach in the new, state-of-the art teaching and learning facility, which includes classrooms with round tables, movable seats, and advanced technology.

Finally, universities should provide support for a campus teaching and learning expert and an FLC. These resources were fundamental in the transition process of our faculty members. FLCs may be discipline-based (Marbach-Ad et al., 2010) or campus-wide (Cox, 2001). FLCs and teaching and learning experts can provide pedagogical and curricular guidance, as well as emotional support for the stressors associated with teaching.

\section{ACKNOWLEDGMENTS}

This work has been approved by the University of Maryland Institutional Review Board (IRB protocol 601750-2). We thank our teaching team members who participated in the study.

\section{REFERENCES}

American Association for the Advancement of Science (2011). Vision and Change in Undergraduate Biology Education: A Call to Action, Washington, DC. http://visionandchange.org/files/2011/03/Revised-Vision-and -Change-Final-Report.pdf (accessed 8 November 2016).

Andrews TC, Lemons PP (2015). It's personal: biology instructors prioritize personal evidence over empirical evidence in teaching decisions. CBE Life Sci Educ 14, ar7

Baldwin RG (2009). The climate for undergraduate teaching and learning in STEM fields. New Dir Teach Learn 117, 9-17.

Bloom BS, Krathwohl DR (1956). Taxonomy of Educational Objectives: The Classification of Educational Goals, Handbook 1: Cognitive Domain, New York: Longmans

Bourrie DM, Cegielski CG, Jones-Farmer LA, Sankar CS (2014). Identifying characteristics of dissemination success using an expert panel. Decision Sci J Innov Educ 12, 357-380.

Brownell SE, Tanner KD (2012). Barriers to faculty pedagogical change: lack of training, time, incentives, and... tensions with professional identity? CBE Life Sci Educ 11, 339-346. 
Carleton KL, Rietschel CH, Marbach-Ad G (2017). Group active engagements using quantitative modeling of physiology concepts in large-enrollment biology classes. J Microbiol Biol Educ 17 (in press).

Connolly MR, Seymour E (2015). Why Theories of Change Matter (WCER Working Paper No. 2015-2). www.wcer.wisc.edu/publications/workingPapers/ papers.php (accessed 8 November 2016).

Cox MD (2001). Faculty learning communities: change agents for transforming institutions into learning organizations. To Improve the Academy 19, 69-93.

Creswell JW (2003). Research Design: Qualitative, Quantitative, and Mixed Methods Approaches, 2nd ed., Thousand Oaks, CA: Sage.

Dancy M, Henderson C (2010). Pedagogical practices and instructional change of physics faculty. Am J Phys 78, 1056-1063.

Ebert-May D, Derting TL, Hodder J, Momsen JL, Long TM, Jardeleza SE (2011). What we say is not what we do: effective evaluation of faculty professional development programs. BioScience 61, 550-558.

Eddy S, Hogan K (2014). Getting under the hood: how and for whom does increasing course structure work? CBE Life Sci Educ 13, 453-468.

Ellsworth JB (2000). Surviving Change: A Survey of Educational Change Models, Washington, DC: Office of Educational Research and Improvement.

Fairweather J, Colbeck C, Paulson K, Campbell C, Bjorklund S, Malewski E (1996). Engineering Coalition of Schools for Excellence and Leadership (ECSEL): Year 6, University Park: Center for the Study of Higher Education, Penn State University.

Felder RM (1993). Reaching the second tier. J Coll Sci Teach 23, 286-290.

Fink LD (2013). Creating Significant Learning Experiences: An Integrated Approach to Designing College Courses, Hoboken, NJ: Wiley.

Freeman S, Eddy S, McDonough M, Smith MK, Okoroafor N, Jordt H, Wenderoth MP (2014). Active learning increases student performance in science, engineering, and mathematics. Proc Natl Acad Sci USA 111, 8410-8415.

Haag ES, Marbach-Ad G (2017). Quantitative modeling of membrane transport and anisogamy by small groups within a large-enrollment organismal biology course. J Microbiol Biol Educ 17 (in press).

Haak DC, HilleRisLambers J, Pitre E, Freeman S (2011). Increased structure and active learning reduce the achievement gap in introductory biology. Science 332, 1213-1216.

Hamdan N, McKnight P, McKnight K, Arfstrom KM (2013). A review of flipped learning. Flipped Learning Network. flippedlearning.org/wp-content/ uploads/2016/07/LitReview_FlippedLearning.pdf (accessed 8 November 2016).

Hammer D (1994). Epistemological beliefs in introductory physics. Cogn Instr 12, 151-183.

Handelsman J, Miller S, Pfund C (2007). Scientific Teaching, New York: Freeman.

Hart Research Associates (2015). Falling Short? College Learning and Career Success, Washington, DC.

Henderson C (2005). The challenges of instructional change under the best of circumstances: a case study of one college physics instructor. Am J Phys 73, 778-786.

Henderson C, Dancy MH (2007). Barriers to the use of research-based instructional strategies: the influence of both individual and situational characteristics. Phys Rev Spec Top Phys Educ Res 3, 020102.

Jensen JL, Kummer TA, Godoy PD (2015). Improvements from a flipped classroom may simply be the fruits of active learning. CBE Life Sci Educ $14, \operatorname{ar} 5$.

Johnson DW, Johnson RT, Holubec EJ, Roy P (1984). Circles of Learning: Cooperation in the Classroom, Alexandria, VA: Association for Supervision and Curriculum Development.
Kezar A, Gehrke S, Elrod S (2015). Implicit theories of change as a barrier to change on college campuses: an examination of STEM reform. Rev High Educ 38, 479-506.

Marbach-Ad G, McAdams KC, Benson S, Briken V, Cathcart L, Chase M, El-Sayed NM, Frauwirth K, Fredericksen B, Joseph SW, Lee V (2010). A model for using a concept inventory as a tool for students' assessment and faculty professional development. CBE Life Sci Educ 9, 408-416.

Marbach-Ad G, Rietschel C, Saluja N, Carleton KL, Haag E (2017). The use of group activities in introductory biology supports learning gains and uniquely benefits high-achieving students. J Microbiol Biol Educ 17 (in press)

Maykut P, Morehouse R (1994). Beginning Qualitative Research: A Philosophic and Practical Approach, Bristol, PA: Falmer.

McKeachie W, Svinicki M (2006). McKeachie's Teaching Tips: Strategies, Research, and Theory for College and University Teachers, Boston. MA: Houghton Mifflin.

Merriam SB (2009). Qualitative Research: A Guide to Design and Implementation, San Francisco, CA: Jossey-Bass.

Michaelsen LK, Black RH (1994). Building learning teams: the key to harnessing the power of small groups in education. In: Collaborative Learning: A Sourcebook for Higher Education, vol. 2, University Park: National Center on Postsecondary Teaching, Learning, and Assessment, Pennsylvania State University, 65-81.

Michaelsen LK, Knight AB, Fink LD (2004). Team-Based Learning: A Transformative Use of Small Groups in College Teaching, Sterling, VA: Stylus.

Michaelsen LK, Sweet M, Parmelee DX (eds.) (2008). In: Team-Based Learning: Small Group Learning's Next Big Step, New Directions for Teaching and Learning, Number 116, Hoboken, NJ: Wiley.

Okebukola PA (1986). Cooperative learning and students' attitudes to laboratory work. School Sci Math 86, 582-590.

Otero V, Pollock S, Finkelstein N (2010). A physics department's role in preparing physics teachers: the Colorado learning assistant model. Am J Phys 78, 1218-1224.

Preszler RW (2009). Replacing lecture with peer-led workshops improves student learning. CBE Life Sci Educ 8, 182-192.

Rogers EM (2003). Diffusion of Innovations, 5th ed., New York: The Free Press.

Schalk KA, McGinnis JR, Harring JR, Hendrickson A, Smith AC (2009). The undergraduate teaching assistant experience offers opportunities similar to the undergraduate research experience. J Microbiol Educ 10, 32-42.

Seidel SB, Tanner KD (2013). What if students revolt?-Considering student resistance: origins, options, and opportunities for investigation. CBE Life Sci Educ 12, 586-595.

Seymour E, Hewitt NM (1997). Talking about Leaving: Why Undergraduates Leave the Sciences, Boulder, CO: Westview.

Shekhar P, Demonbrun M, Borrego M, Finelli C, Prince M, Henderson C Waters $C$ (2015). Development of an observation protocol to study undergraduate engineering student resistance to active learning. Int J Eng Educ 31, 597-609.

Watson WE, Kumar K, Michaelsen LK (1993). Cultural diversity's impact on interaction process and performance: comparing homogeneous and diverse task groups. Acad Manage J 36, 590-602.

Weimer M (2013). Learner-Centered Teaching, San Francisco: Jossey-Bass.

Wieman C, Perkins K, Gilbert S (2010). Transforming science education at large research universities: a case study in progress. Change 42, 6-14.

Wiggins GP, McTighe J (2005). Understanding by Design Alexandria, VA: Association for Supervision and Curriculum Development.

Yin RK (2003). Case Study Research: Design and Methods, 3rd ed., Thousand Oaks, CA: Sage. 